\title{
USING SAFETY ENVIRONMENT ESSENTIAL OIL TO IMPROVE QUALITY AND STORAGE ABILITY FOR GRAPES
}

\author{
Mohammed H. Hatem ${ }^{1}$ - Abd el-Aal Z. Taieb ${ }^{2}$ - Ibrahim A. Shalaby ${ }^{3}$ - \\ Raghda Mohammed Attia ${ }^{4}$
}

\begin{abstract}
Table grapes are one of the oldest fruit known their cultivation in Egypt. Gray mold caused by Botrytis cinerea the most important postharvest disease of table grapes. The fungus grows vigorously on harvested grapes and can spread among berries even at low temperatures $\left(-0.5^{\circ} \mathrm{C}\right)$. The most common commercial method to control decay is the use of $\mathrm{SO}_{2}$ during cold storage. The $\mathrm{SO}_{2}$ is harmful to human health and environmental. The main objective is found alternative of Sulfur dioxide pad. In this study used two varieties of grapes: - 1)Sugraone Seedless: It is a white seedless, and 2)Crimson Seedless:It is a red seedless. With threetreatments. 1) Were used LifeSpan (MAP) and essential oil pad. 2) Were used LifeSpan and essential oil was sprayed before harvest with 24 hour .3) were used LifeSpan as a kind of Modified Atmosphere Packing only (control treatment). Measurements the properties which the quality of grapes depend on its like Total Soluble Solids (T.S.S \%), total acidity, weight losses, shatter percentage, brown and rots percentage and diameter storage grapes at Maintaining a low temperature is a primary consideration in securing cooling of grapes it's $1 \pm 1$. However, maintaining a high relative humidity of $95 \%$ and above during the storage is very important to minimize moisture loss and keep the stems in good condition and green.From this experiment, the LifeSpan and Bail oil was the best treatment with Sugraone (white grapes) and Crimson (red grapes). It got storage period until 60 days with very good quality.
\end{abstract}

Keyword: -Grape-Modified Atmosphere Packing-essential oil-Quality.

\footnotetext{
${ }^{1}$ Professor, Ag. Eng. Dept.Faculty of Agriculture - Cairo University

${ }^{2}$ Associate Professor, Ag. Eng. Dept.Faculty of Agriculture - Cairo University

${ }^{3}$ Associate Professor, Medicinal and Aromatic plants, Dept.

${ }^{4}$ Agricultural Engineer-Horticulture Research Institute- Agricultural Research Center
} 


\section{INTRODUCTION}

7 able grape is one of the fruit with the highest input of technologies but even with an intense hand labour activity and

the price on the market is one of the higher in the fruit sector. Handling and packing (labour cost and packing materials) weight upon $25-30 \%$; the cost of refrigerated storage condition engraves for $10 \%$ per month.Costa et al. (2011) reported that another relevant aspect to be taken into great account for maintaining the quality of horticultural commodities is the choice of the appropriate packaging system. Different headspace conditions can be achieved in the package depending on the interactions between respiratory activity of the packaged produce and gas transfer through the polymeric matrix.

\section{* Modified Atmosphere Packaging}

McMillin (2008) defined modified atmosphere packaging (MAP) is the removal and/or replacement of the atmosphere surrounding the product before sealing in vapor-barrier materials.Jobling (2001) reported the main aim of MAPis to change the composition of the atmosphere around the product so that the storage life of the product can be extended.

\section{* Gray mold}

Gray mold caused by Botrytis cinerea the most important postharvest disease of table grapes.In general, Botrytis is an important problem to fruit and vegetables in cold storage and subsequent shipment, because the fungus is able to grow effectively at temperatures just above freezing(Mustafa et al., 2009).Artés-Hernández et al. (2006) reported that the most common commercial method to control decay is the use of $\mathrm{SO}_{2}$ during cold storage, either by fumigation or generators. Meng et al. (2010) reported that the $\mathrm{SO}_{2}$ application usually causes injury to fruits, and is harmful to human health Moreover, due to increased public concern on food safety, $\mathrm{SO}_{2}$ as a fungicide is limited to use for grape storage. For those reasons alternative techniques to $\mathrm{SO}_{2}$ for preserving postharvest table grape quality are being currently investigated.

\section{* Essential oils}

Essential oils are volatile, natural, complex compounds characterized by a strong odour and are formed by aromatic plants as secondary metabolites(Bakkali et al., 2008). The essential oils are thought to play a 
role in the plant defence mechanism against phytopathogenic microorganisms (Mihaliak et al., 1991). Most of the essential oils have been reported to inhibit post-harvest fungi in in vitro conditions(Hidalgo et al., 2002).

The main objective is to study modified atmosphere packaging and found alternative of Sulfur dioxide pad to maintain the environment during storage at low temperature and a high relative humidity of $95 \%$ and above.

\section{MATERIALS AND METHODS}

\section{1) Materials}

\section{a) Grapes}

Two types of grapes (Vitisvinifera L.)were investigated:

\section{1) Sugraone Seedless}

It is a white seedless variety with exceptional large berries for an early, seedless variety. It has a good shelf life. The berries have a slight muscatflavour when fully matured.

\section{2) CrimsonSeedless}

It is a red, mid- to late season seedless variety. It normally ripens one week later Sunred Seedless. Crimson tends to ripen well on the vine, extending the season for seedless grapes. The bunches are attractive, filled with slightly elongated berries of maroon-red color. Flame has a melting crispy flavour and sweet taste.

\section{b) Packs}

\section{LifeSpan (Modified Atmosphere Packing)}

This bag is designed for $9 \mathrm{~kg}$ of Seedless Grape-Special for best performance. Store at $0{ }^{\circ} \mathrm{C}$. Finger 1 shows the work methods of LifeSpan.

Warning: - bag must be opened on removal from cold chain.

Important: liner must be used as stated in packing information sheet supplied. Information supplied as guidance only. Customer must determine suitability for use.

Bag Code: - L612.

Batch No.: D161109. 


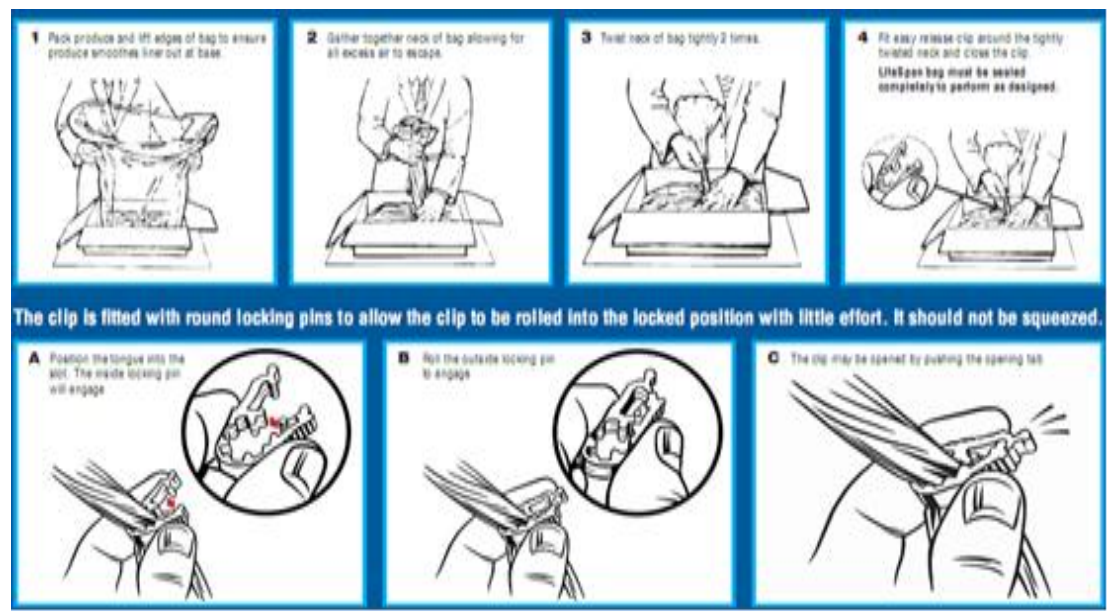

Fig.1. LifeSpan work method

\section{Source of essential oils}

The essential oil was isolated by hydro-distillation through Clevengers apparatus. Fresh plant parts (leaves or Flower or herb) were cut into small pieces and then thoroughly washed with sterilized water. The plant material was then placed in the round-bottom flask of the Clevengers apparatus. The ratio between the plant material and water in the flask was maintained as 1:3. Water was heated to produce steam that carried the most volatile fractions of the aromatic material with it. The steam was then chilled (in a condenser) and the resulting distillate was collected. The essential oil was found to float on the top of the hydrosol (the distilled water component) and was separated off. The extracted oils were dehydrated by the addition of anhydrous sodium sulphate, followed by thorough shaking and standing for 6-8 h and filtration (Tripathi et al., 2008)

\section{2) Packing and alternativeof Sulfur dioxide pad experiment}

This experiment was executed in PICO farm -Badr Center -Tahrir Directorate at season 2012. This experiment was conducted as follow:

\section{A. First Treatment}

Storage two varieties of grapes seedless one is Sugraone Seedless which whiten colour, and anther is Crimson Seedless which red colour. It is storage on $1 \pm 1{ }^{\circ} \mathrm{C}$ and $95 \%$ humidity, using LifeSpan as a kind of Modified Atmosphere Packing and essential oil Pad. 


\section{B. Second Treatment}

Storage two varieties of grapes seedless one is Sugraone Seedless which whiten colour, and anther is Crimson Seedless which red colour. It is storage on $1 \pm 1^{\circ} \mathrm{C}$ and $95 \%$ Humidity, using LifeSpan as a kind of Modified Atmosphere Packing and essential oil was sprayed before harvest with 24 hour .

\section{Third Treatment}

Storagetwo varieties of grapes seedless one is Sugraone Seedless which whiten colour, and anther is CrimsonSeedless which red colour. It is storage on $1 \pm 1^{\circ} \mathrm{C}$ and $95 \%$ Humidity, using LifeSpan as a kind of Modified Atmosphere Packing only.

\section{3) Methods of Analyses}

\section{a. Chemical Properties}

1) Total Soluble Solids (T.S.S \%)

A hand refractometer was used to determine the total soluble solids percentage in fruit juice.

\section{2) Total Acidity}

Total acidity was determined in terms of anhydrous malic acid percentage after titration against $0.1 \mathrm{~N}$ Sodium hydroxide using Phenolnaphaline as an indicator (A.O.A.C., 1995)

$$
\text { Acidity }=\frac{\text { Average Titration }}{\text { The volume of grapes juice }} \times \text { Titration against } \mathrm{NaOH} \times \text { Tartaric acid Strength }
$$

\section{Where:}

The volume of grapes juice is $5 \mathrm{ml}$

Titration against $\mathrm{NaOH}$ is 0.1

Tartaric acid strength is 75 .

\section{3) Sugar: Acid ratio}

The sugar: acid ratio was determined according to the following equation:

$$
\text { Sugar }: \text { Acid ratio }=\frac{\text { Total Soluble Solids }}{\text { Total Acidity }}
$$

\section{b. Physical Properties}

\section{1) Percentage of Weight Losses (\%)}

The percentage weight loss was determined according to the following equation: 
Where:

$$
\text { Weight losses } \%=\frac{W_{0}-W_{t}}{W_{0}} \times 100 \%
$$

$\mathrm{W}_{0}$ : Weight bunch of grapes at zero time $(\mathrm{g})$.

$\mathrm{W}_{\mathrm{t}}$ : Weight bunch of grapes at $(\mathrm{T})$ time $(\mathrm{g})$.

The sample weight was determined by means of a digital precision balance $( \pm 0.1 \mathrm{~g})$ (Gibertini Europe, Italy). At each sampling time, three replicates were made.

\section{2) Percentage of Shatter $(\%)$}

The percentage of shatter was determined according to the following expression

Where

$$
\text { Shatter } \%=\frac{S_{t}}{W_{0}} \times 100 \%
$$

$\mathrm{W}_{0}$ : Weight bunch of grapes at zero time $(\mathrm{g})$.

$\mathrm{S}_{\mathrm{t}}$ :Weight shatter grapes berries at $(\mathrm{T})$ time $(\mathrm{g})$.

\section{3) Percentage of Brown (\%)}

The percentage of brown was determined according to the following expression

$$
\text { Brown } \%=\frac{B_{t}}{W_{0}} \times 100 \%
$$

Where:

$\mathrm{W}_{0}$ : Weight bunch of grapes at zero time $(\mathrm{g})$.

$\mathrm{B}_{\mathrm{t}}$ : Weight brown grapes berries at $(\mathrm{T})$ time $(\mathrm{g})$.

\section{4) Percentage of Rot (\%)}

The percentage of rot was determined according to the following expression

$$
\text { Rot } \%=\frac{R_{t}}{W_{0}} \times 100 \%
$$

Where:

$\mathrm{W}_{0}$ : Weight bunch of grapes at zero time $(\mathrm{g})$.

$\mathrm{R}_{\mathrm{t}}$ : Weight rot grapes berries at $(\mathrm{T})$ time $(\mathrm{g})$.

\section{Specifications exportbunch}

\section{RESULTS AND DISCUSSION}

a. T.S.S \% : not less than $16: 17 \%$

b. Berry Size: not less than $17 \mathrm{~mm}$.

c. Bunch Weight is750:350gm. 
d. Bunch disjointed.

e. Thebunchlengthis $15: 13 \mathrm{~cm}$.

f. Similar berrieswithinthebunch.

g. Free from insect disease (trips andspider) and fungal diseases(molds).

\section{Analysis of essential oils}

The main components of Basil oil was shows in table 1 and Fig. 2 shown the Gas Chromatography of Basil essential oil.

\section{Table 1. The main componentsof Basil oil}

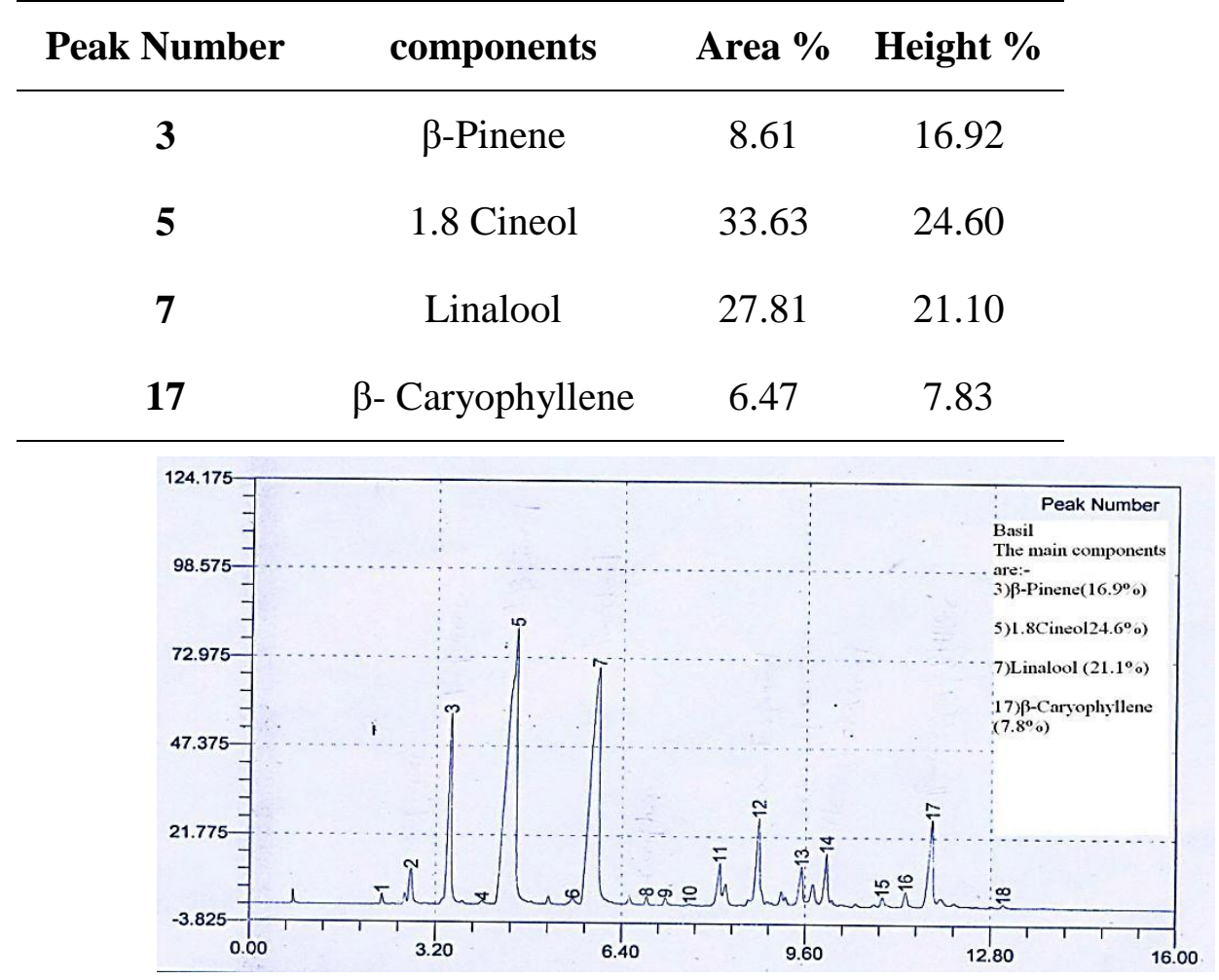

Fig.2. Gas Chromatography of Basil essential oil

3. Effect of LifeSpan, LifeSpan and spray basil oil before $24 \mathrm{~h}$ of harvest and LifeSpan and basil oil pad on chemical and physical properties during storage Sugraone and crimson grapes.

\section{a. Total Soluble Solids (T.S.S \%)}

Generally T.S.S \% in Sugraone and Crimson at $1 \pm 1{ }^{\circ} \mathrm{C}$ and $95 \%$ Humidityduring storage in three treatments of used basil oil and LifeSpan was increased as show in Fig.3and 4. 


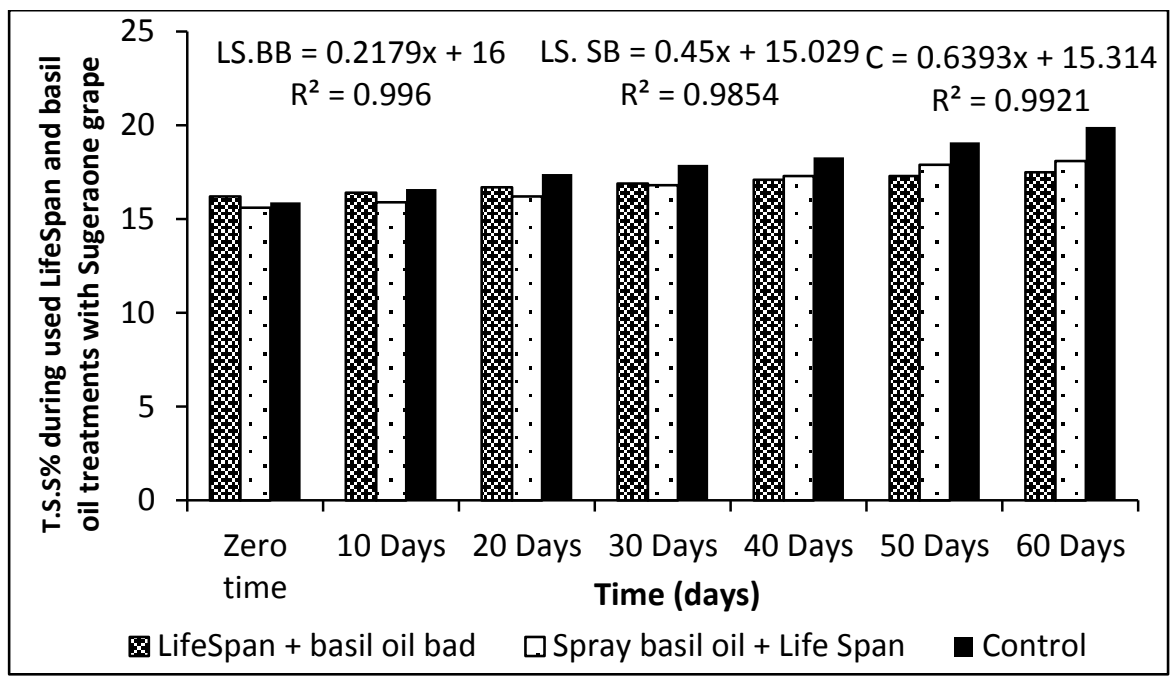

Fig.3. The relationship between T.S.S\% and time during storage period of Sugarone grapes uesing LifeSpan and basil oil treatment.

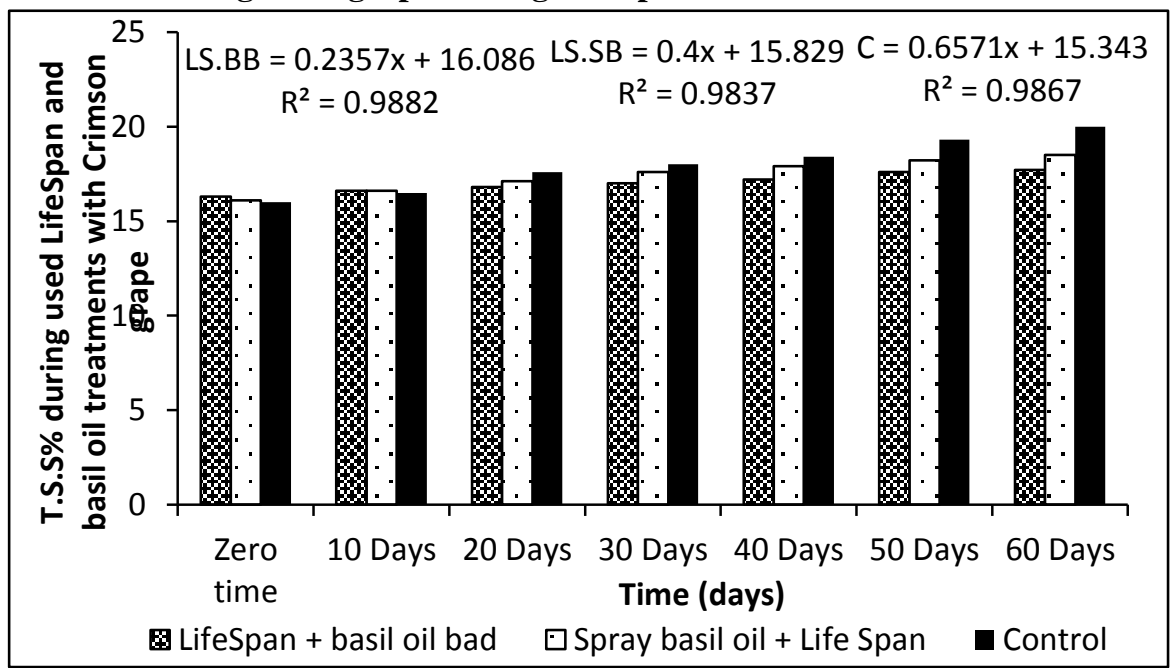

Fig..4. The relationship between T.S.S\% and time during storage period of Crimson grapes uesing LifeSpan and basil oil treatment.

T.S.S \% in all the tested treatments was increased during storage period. The increases with basil oil treatments were less than the increase with control treatment. Basil oil pad treatment was the best treatment with two varieties of grapes.

The superior treatments which keeping T.S.S\% of grapes fruits was basil oil pad treatment $(4000 \mathrm{ppm})$ and LifeSpan compared with the other tested 


\section{b. Acidity}

Generally acidity in Sugraone and Crimson at $1 \pm 1{ }^{\circ} \mathrm{C}$ and $95 \%$ Humidityduring storage in three treatments of used basil oil and LifeSpan was increased as show in Fig. 5 and 6.

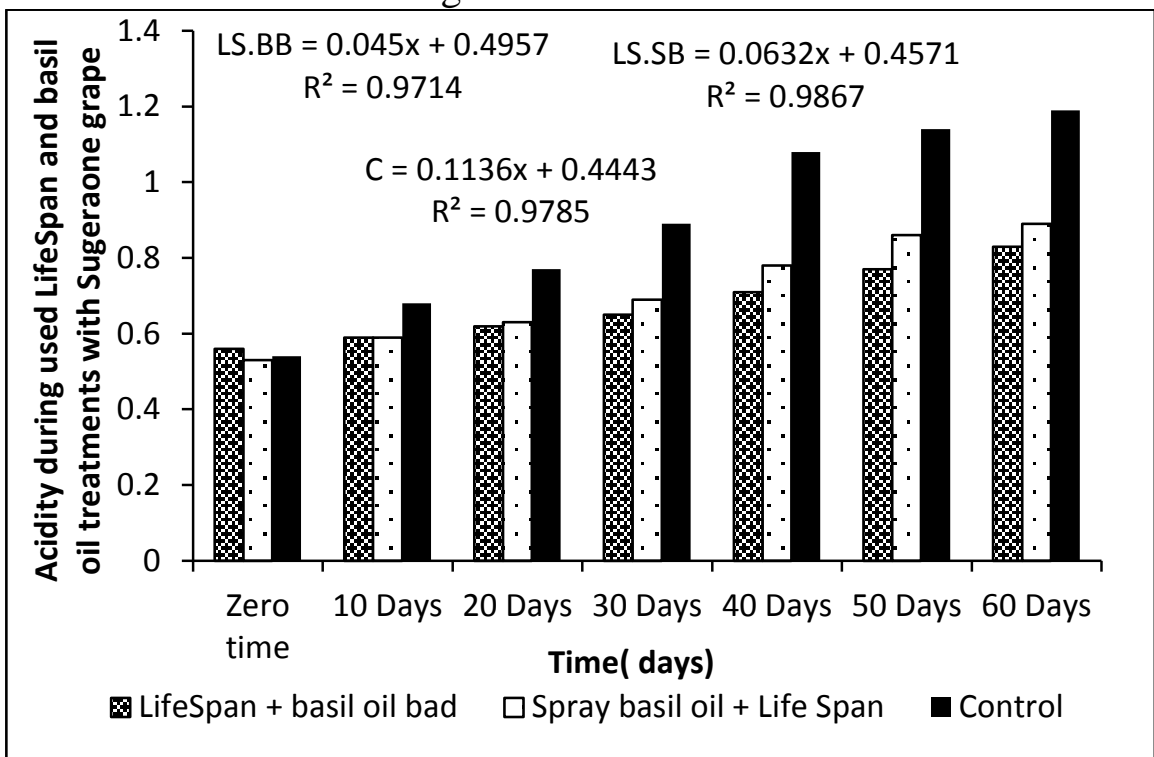

Fig.5. The relationship between acidity and time during storage period of Sugarone grapes uesing LifeSpan and basil oil treatment.

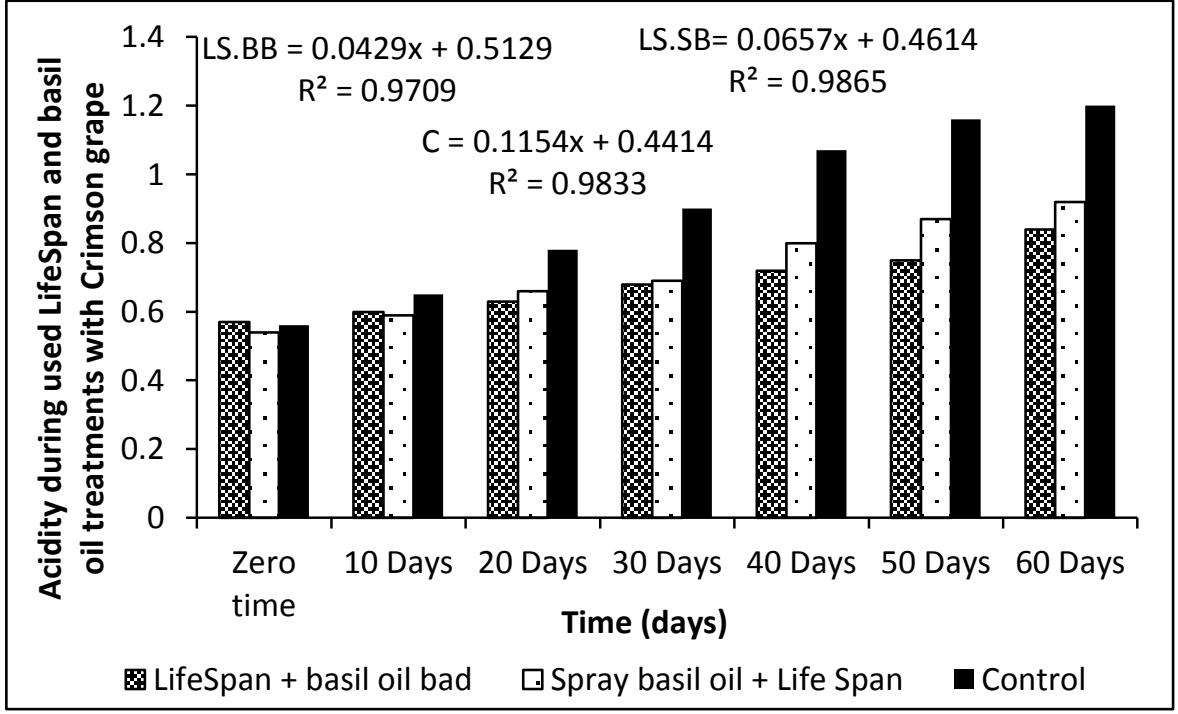

Fig.6. The relationship between acidity and time during storage period of Crimson grapes uesing LifeSpan and basil oil treatment.

The acidityin all the tested treatments was increased during storage period. The increases with basil oil treatments were less than the increase 
with control treatment. Basil oil pad treatment was the best treatment with two varieties of grapes.

The superior treatments which keeping acidityof grapes fruits was basil oil pad treatment $(4000 \mathrm{ppm})$ and LifeSpan compared with the other tested.

\section{c. Sugar: Acid ratio}

Generally sugar: acid ratio in Sugraone and Crimson at $1 \pm 1{ }^{\circ} \mathrm{C}$ and $95 \%$ Humidityduring storage in three treatments of used basil oil and LifeSpan was decreased as show in Fig.7 and 8.

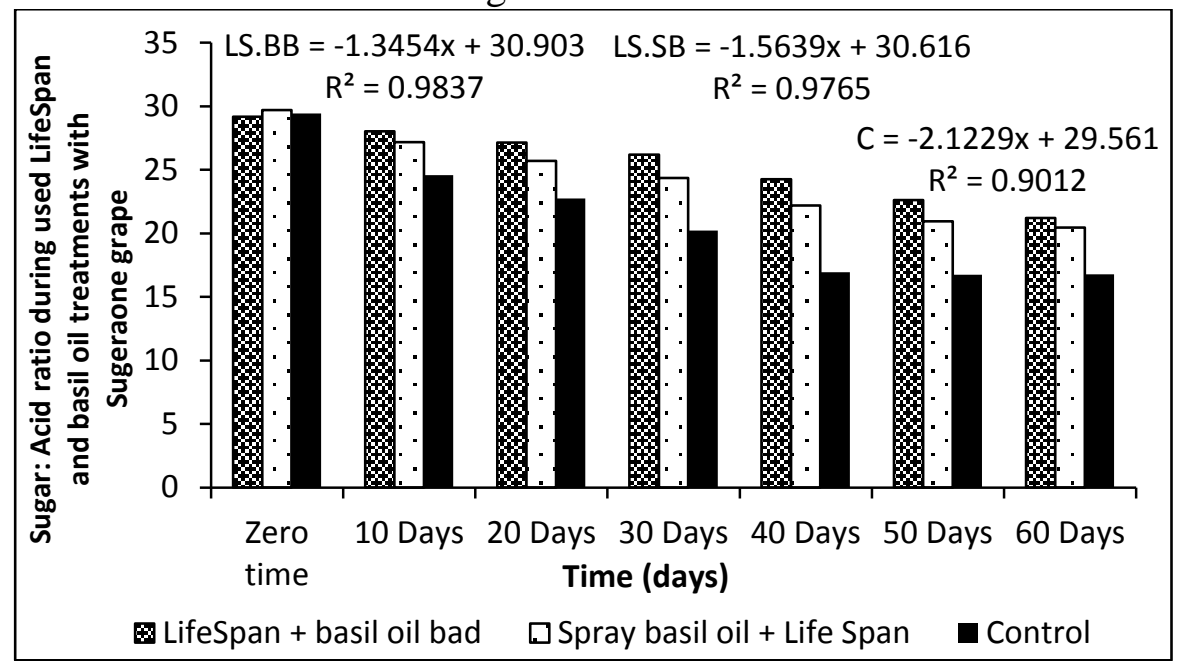

Fig..7. The relationship between sugars: acid ratio and time during storage period of Sugarone grapes uesing LifeSpan and basil oil treatment.

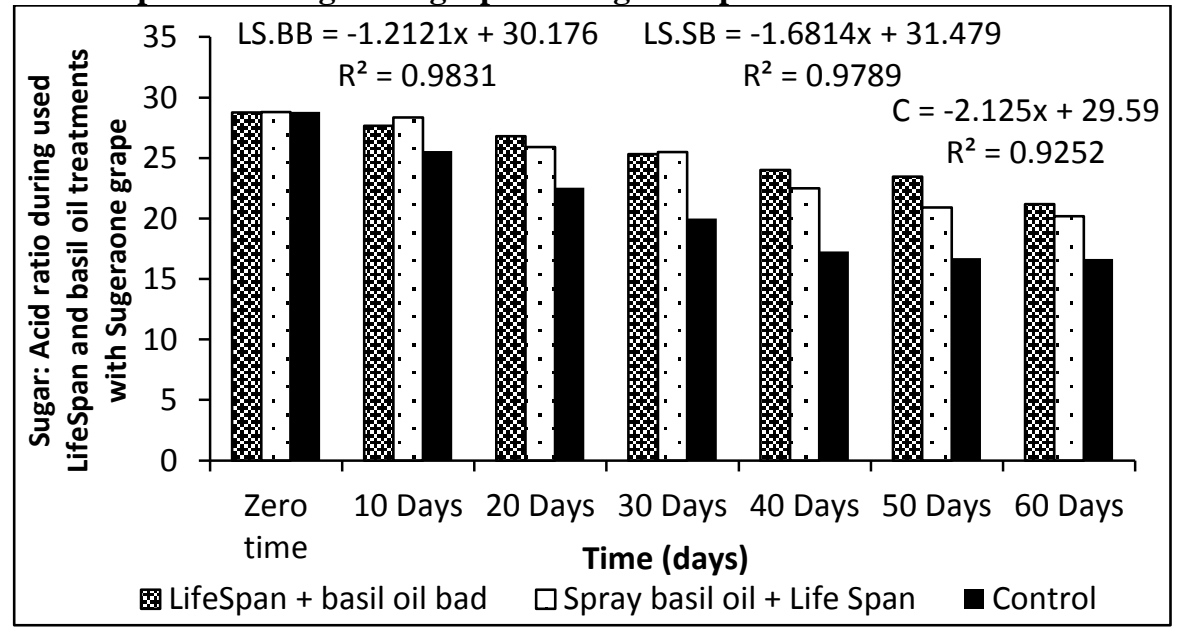

Fig.8. The relationship between sugars: acid ratio and time during storage period of Crimson grapes uesing LifeSpan and basil oil treatment. 
The sugar: acid ratio in all the tested treatments was increased during storage period. The increases with basil oil treatments were less than the increase with control treatment. Basil oil pad treatment was the best treatment with two varieties of grapes.

The superior treatments which keeping sugar: acid ratio of grapes fruits was basil oil pad treatment (4000 ppm) and LifeSpan compared with the other tested.

\section{d. Weight losses percentage $\%$}

Generally weight losses\% in Sugraone and Crimson at $1 \pm 1{ }^{\circ} \mathrm{C}$ and $95 \%$ Humidityduring storage in three treatments of used basil oil and LifeSpan was increased as show in Fig.9 and 10.

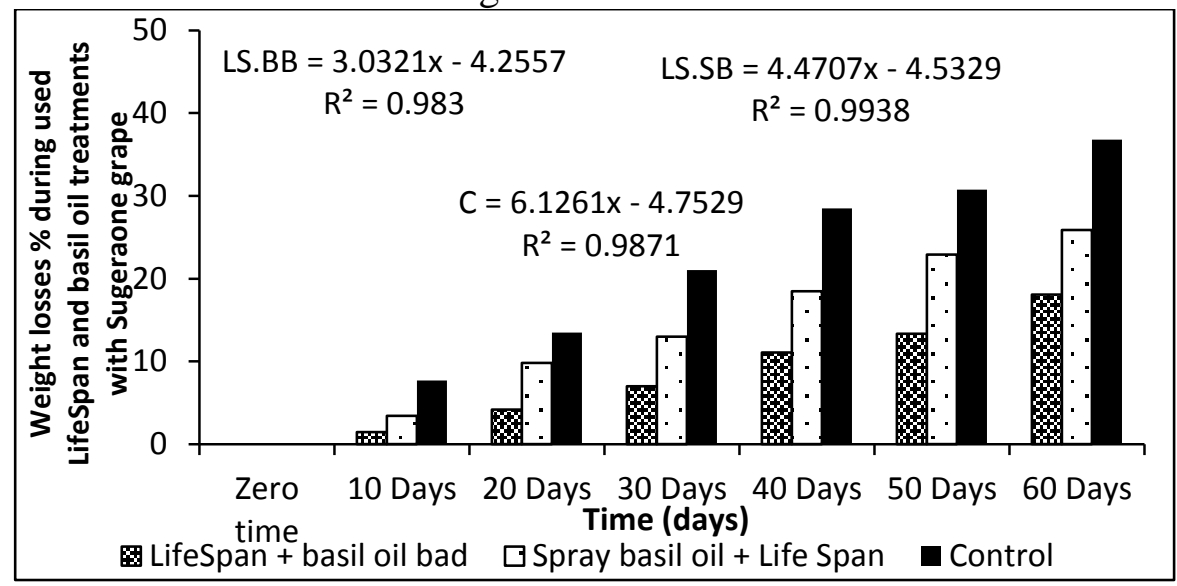

Fig.9. The relationship between weight losses\% and time during storage period of Sugarone grapes uesing LifeSpan and basil oil treatment.

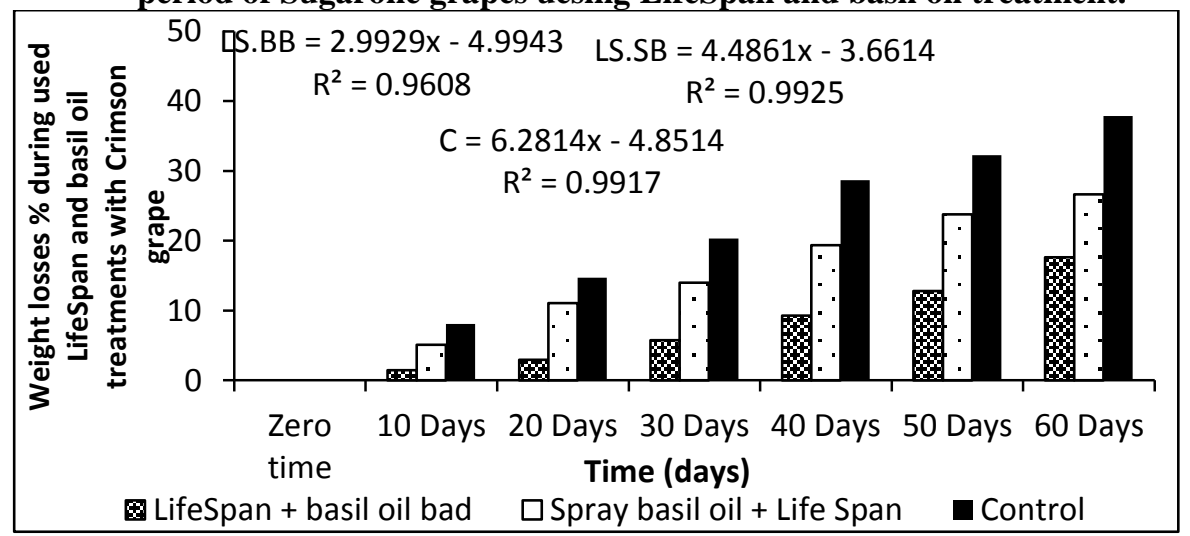

Fig.10. The relationship between weight losses\% and time during storage period of Crimson grapes uesing LifeSpan and basil oil treatment.

The weight losses\%in all the tested treatments was increased during storage period. The increases with basil oil treatments were less than the 
increase with control treatment. Basil oil pad treatment was the best treatment with two varieties of grapes.

The superior treatments which keeping weight losses\% of grapes fruits was basil oil pad treatment (4000 ppm) and LifeSpan compared with the other tested.

\section{e. Shatter percentage $\%$}

Generally shatter\% in Sugraone and Crimson at $1 \pm 1{ }^{\circ} \mathrm{C}$ and $95 \%$ Humidityduring storage in three treatments of used basil oil and LifeSpan was increased as show in Fig. 11 and 12.

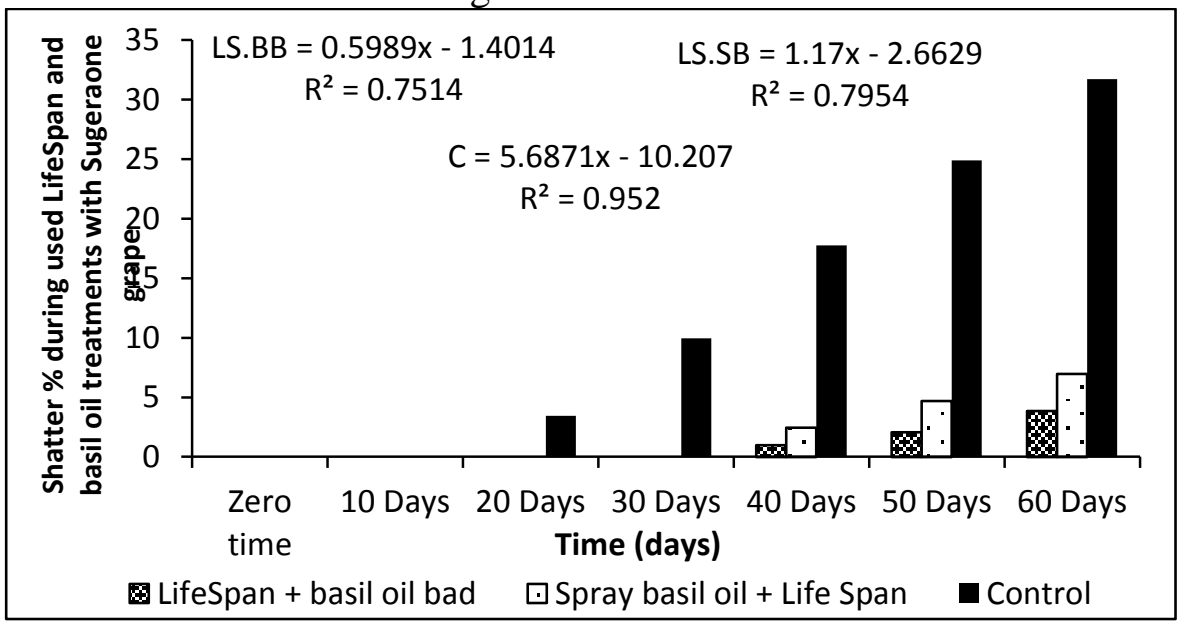

Fig. 11. The relationship between shatter $\%$ and time during storage period of Sugarone grapes uesing LifeSpan and basil oil treatment.

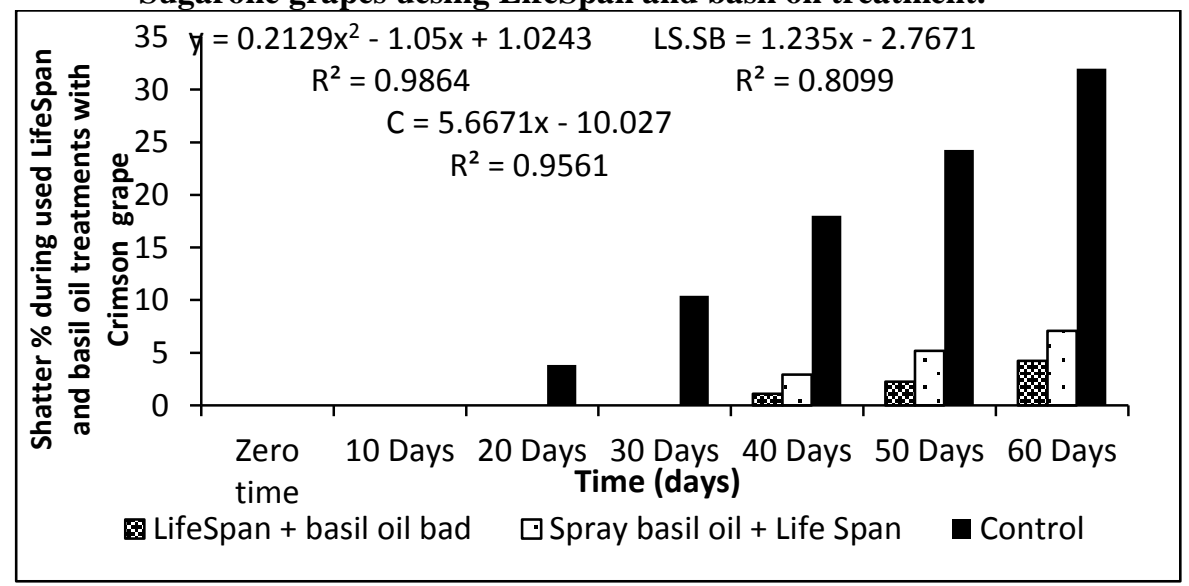

Fig.12. The relationship between shatter $\%$ and time during storage period of Crimson grapes uesing LifeSpan and basil oil treatment.

The shatter in all the tested treatments was increased during storage period. The increases with basil oil treatments were less than the increase 
with control treatment. Basil oil pad treatment was the best treatment with two varieties of grapes.

The superior treatments which keeping shatter $\%$ of grapes fruits was basil oil pad treatment (4000 ppm) and LifeSpan compared with the other tested.

\section{f. Rot percentage \%}

Generally rot $\%$ in Sugraone and Crimson at $1 \pm 1{ }^{\circ} \mathrm{C}$ and $95 \%$ Humidityduring storage in three treatments of used basil oil and LifeSpan was increased as show in Fig.13 and 14.

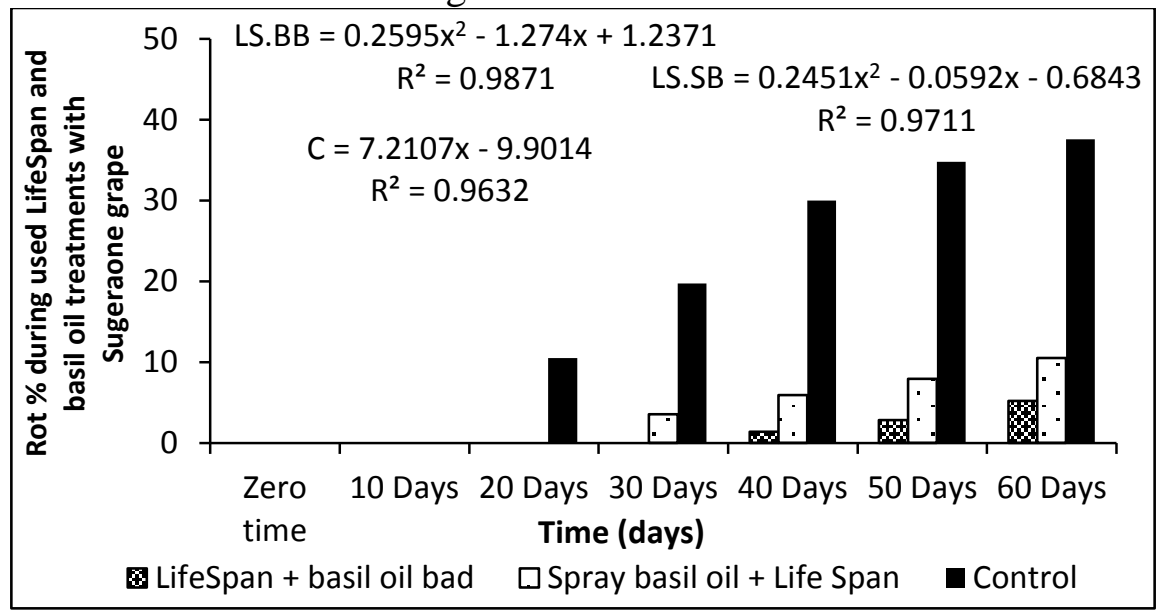

Fig.13. The relationship between rot\% and time during storage period of Sugarone grapes uesing LifeSpan and basil oil treatment.

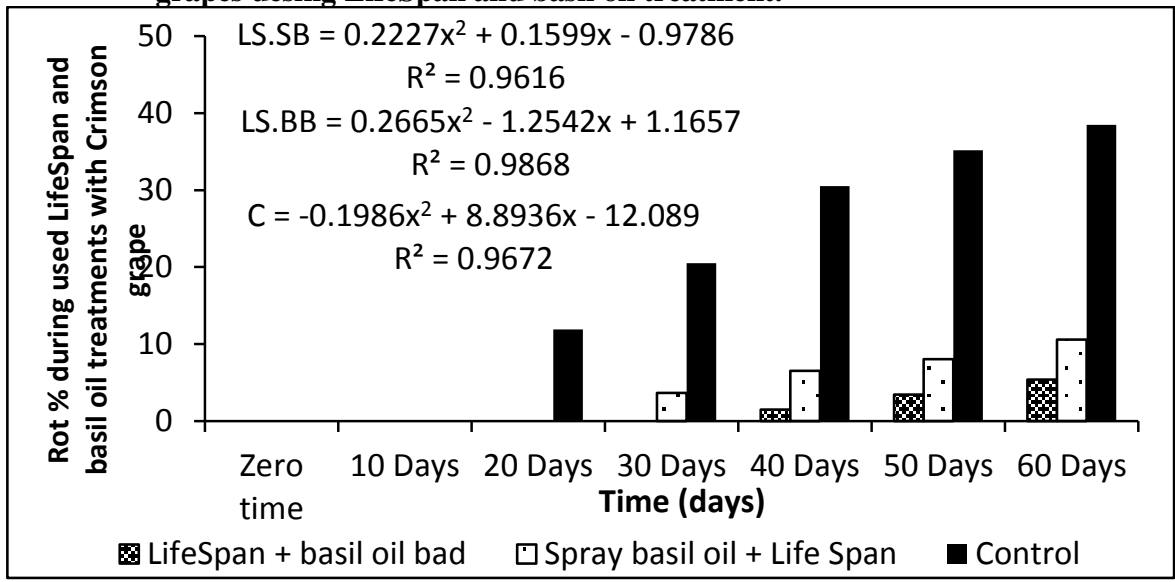

Fig.14. The relationship between rot $\%$ and time during storage period of Crimson grapes uesing LifeSpan and basil oil treatment.

The rotting in all the tested treatments was increased during storage period. The increases with basil oil treatments were less than the increase 
with control treatment. Basil oil pad treatment was the best treatment with two varieties of grapes.

The superior treatments which keeping rot\% of grapes fruits was basil oil pad treatment (4000 ppm) and LifeSpan compared with the other tested.

\section{g. Brown percentage \%}

Generally brown\% in Sugraone and Crimson at $1 \pm 1{ }^{\circ} \mathrm{C}$ and $95 \%$ Humidityduring storage in three treatments of used basil oil and LifeSpan was increased as show in Fig. 15 and 16.

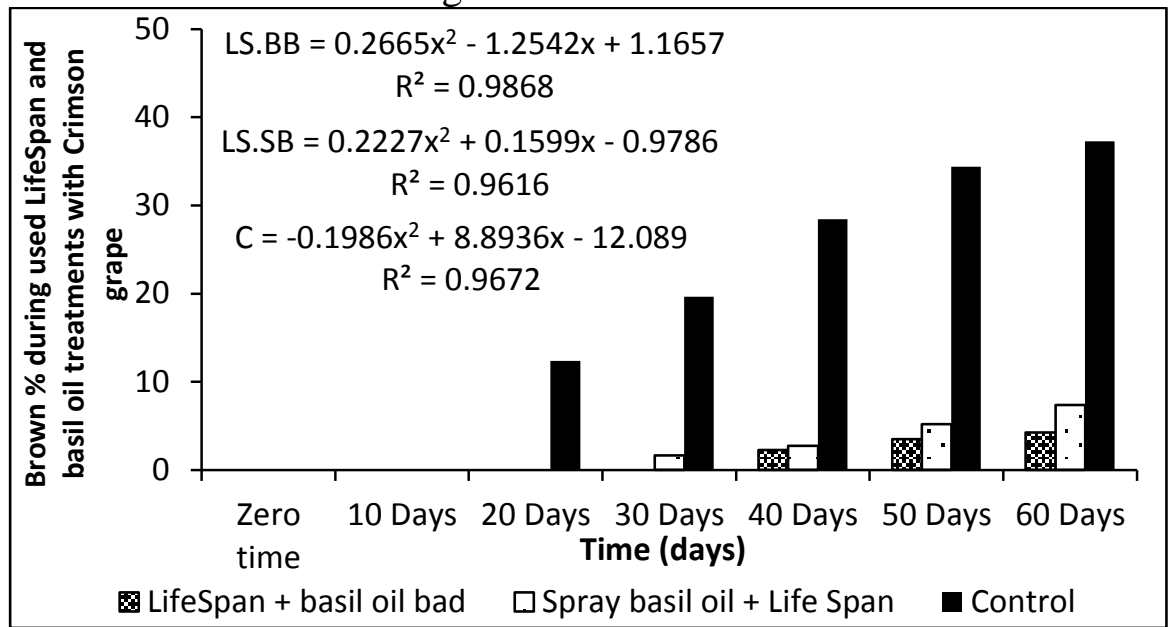

Fig.15. The relationship between brown\% and time during storage period of Sugarone grapes uesing LifeSpan and basil oil treatment.

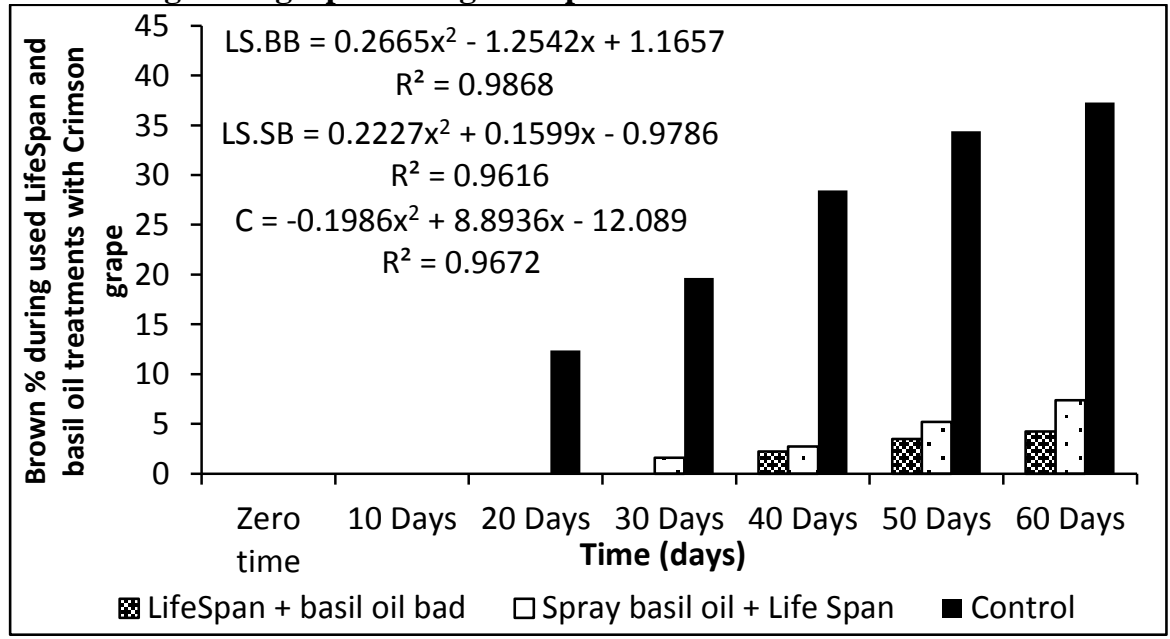

Fig.16. The relationship between brown\% and time during storage period of Crimson grapes uesing LifeSpan and basil oil treatment.

The brown in all the tested treatments was increased during storage period. The increases with basil oil treatments were less than the increase with control 
treatment. Basil oil pad treatment was the best treatment with two varieties of grapes.

The superior treatments which keeping brown $\%$ of grapes fruits was basil oil pad treatment (4000 ppm) and LifeSpan compared with the other tested.

\section{CONCLUSION}

From this experiment, the LifeSpan and Bail oil were the best treatment with Sugraone (white grapes) and Crimson (red grapes). It got storage period until 60 days with very good quality.

\section{REFERENCES}

A.O.A.C. (1995). Official and tentative methods of analysis of the Association of Official Agricultural Chemists. pp.158, 8th ed. Washington D.C. .

Artés-Hernández, F.; Tomás-Barberán, F.A. and Artés, F. (2006). Modified atmosphere packaging preserves quality of SO2-free 'Superior seedless' table grapes. Postharvest Biology and Technology, 39(2), 146-154.

Bakkali, F.; Averbeck, S.; Averbeck, D. and Idaomar, M. (2008). Biological effects of essential oils - A review. Food and Chemical Toxicology, 46(2), 446-475.

Costa, C.; Lucera, A.; Conte, A.; Mastromatteo, M.; Speranza, B.; Antonacci, A. and Del-Nobile, M.A. (2011). Effects of passive and active modified atmosphere packaging conditions on ready-to-eat table grape. Journal of Food Engineering, 102(2), 115-121.

Hidalgo, P.J.; Ubera, J.L.; Santos, J.A.; LaFont, F.; Castelanos, C.; Palomino, A. and Roman, M. (2002). Essential oils in Culamintha sylvatica. Bromf. ssp. ascedens (Jorden) P.W. Ball wild and cultivated productions and antifungal activity. J Essential Oil Res 14:68-71.

Jobling, J. (2001). Modified atmosphere packaging: Not as simple as it seems. Sydney Postharvest Laboratory Information Sheet. Good Fruit and Vegetables Magazine 11(5).

McMillin, K.W. (2008). Review where is MAP Going? A review and future potential of modified atmosphere packaging for meat. Meat Science 80 (2008) 43-65(www.elsevier.com/locate/meatsci).

Meng, Xiang-Hong; Qin, Guo-Zheng and Tian, Shi-Ping. (2010). Influences of preharvest spraying Cryptococcus laurentii combined with postharvest chitosan coating on postharvest diseases and quality of table grapes in storage. LWT - Food Science and Technology, 43(4), 596-601.

Mihaliak, C.A.; Gershenzo, J. and Croteau, R. (1991). Lack of rapid monoterpene turnover in rooted plants, implications for theories of plant chemical defense. Oecologia 87:373-376. 
Mustafa, C.; Kalpulov, T.; Zutahy, Y.; Ish-shalom, S.; Lurie, S. and Lichter, A. (2009). Quantitative and qualitative analysis of Botrytis inoculated on table grapes by qPCR and antibodies. Postharvest Biology and Technology 52 (2009) 235-239.

Tripathi, P.; Dubey, N. K. and Shukla, A. K. (2008). Use of some essential oils as post-harvest botanical fungicides in the management of grey mould of grapes caused by Botrytis cinerea. World J Microbiol Biotechnol(DOI 10.1007/s11274-007-9435-2), (2008) 2024:2039-2046.

\section{الملخص العربيى}

\section{استخدام الزيوت الطبية لتحسين الجوده والقدرة التخزينية للعنب

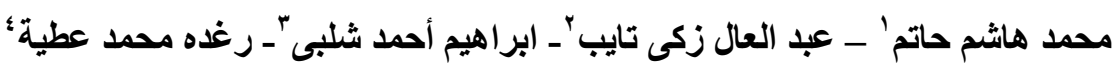

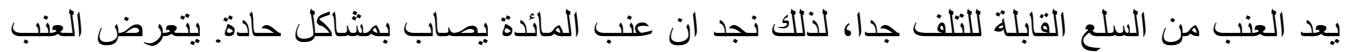

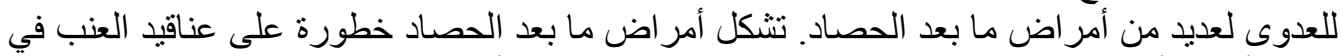

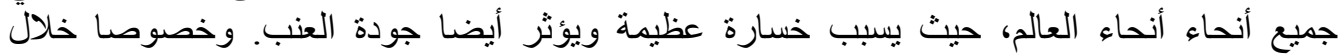

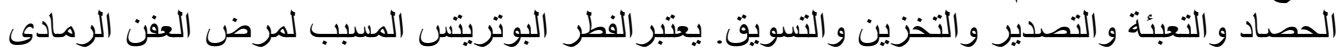

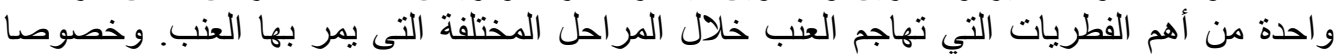

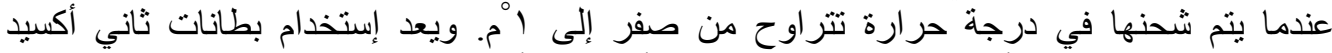

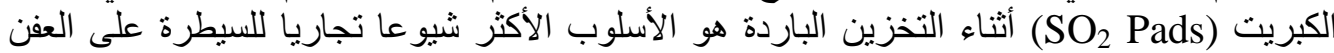

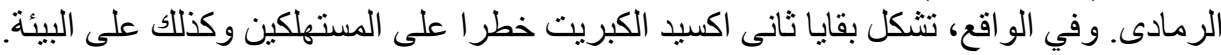

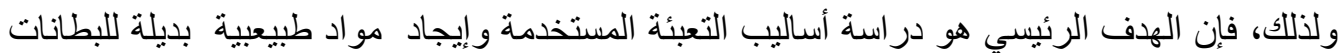

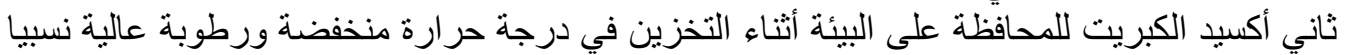

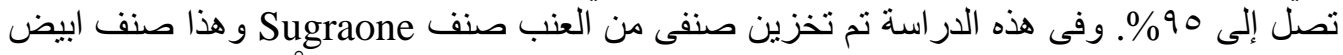

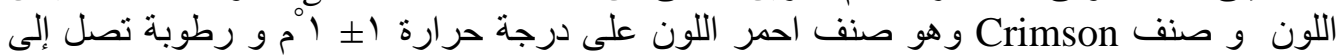
\% 90

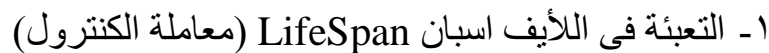

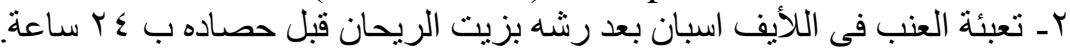

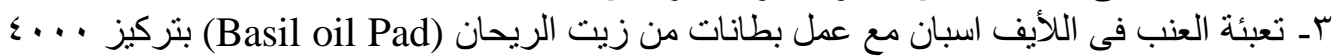
جزء فى المليون.

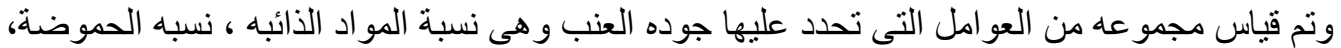
نسبه الفقد فى الوزن، نسبه الفرطو وكذلك نسبه الاعفان وتلون الثنار الثار باللون البنى.

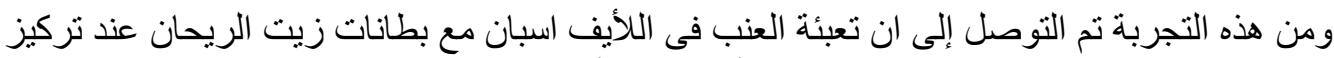

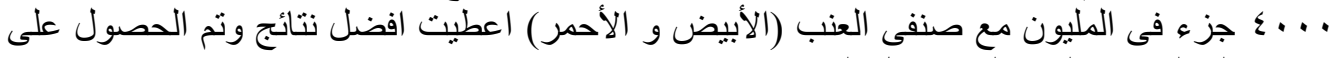

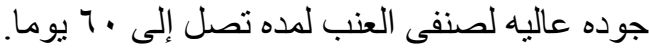

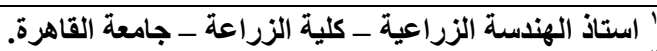

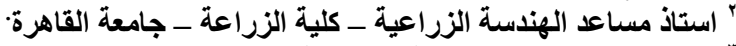

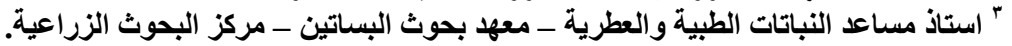
" مهنسة زراعية ـ معهل بحوث البساتين ـ مركز البحوث الزراعية. 